Article

\title{
Sustainability Learning in Education for Sustainable Development for 2030: An Observational Study Regarding Environmental Psychology and Responsible Behavior through Rural Community Travel
}

\author{
Fang-Hua Chen ${ }^{1,2}$, Chang-Ching Tsai ${ }^{3}$, Pei-Yin Chung ${ }^{4}(\mathbb{D})$ and Wei-Shuo Lo ${ }^{2, *(D)}$ \\ 1 Program in Tourism and Hospitality Section, Business Intelligence School, National Kaohsiung University of \\ Science and Technology, Kaohsiung City 807, Taiwan; x00010694@meiho.edu.tw \\ 2 Department of Tourism, Meiho University, Pingtung City 912, Taiwan \\ 3 Department of Tourism Management, National Kaohsiung University of Science and Technology, \\ Kaohsiung City 807, Taiwan; james@nkust.edu.tw \\ 4 Department of Nursing, Meiho University, Pingtung City 912, Taiwan; x00003223@meiho.edu.tw \\ * Correspondence: x2134@meiho.edu.tw; Tel.: +886-8-779-9821 (ext. 6300)
}

check for updates

Citation: Chen, F.-H.; Tsai, C.-C.; Chung, P.-Y.; Lo, W.-S. Sustainability Learning in Education for Sustainable Development for 2030: An Observational Study Regarding Environmental Psychology and Responsible Behavior through Rural Community Travel. Sustainability 2022, 14, 2779. https://doi.org/ $10.3390 /$ su14052779

Academic Editors:

Antonio-Manuel Rodríguez-García, María-Natalia Campos-Soto and Juan Carlos de la Cruz-Campos

Received: 25 January 2022

Accepted: 23 February 2022

Published: 26 February 2022

Publisher's Note: MDPI stays neutral with regard to jurisdictional claims in published maps and institutional affiliations.

Copyright: (C) 2022 by the authors. Licensee MDPI, Basel, Switzerland. This article is an open access article distributed under the terms and conditions of the Creative Commons Attribution (CC BY) license (https:// creativecommons.org/licenses/by/ $4.0 /)$.

\begin{abstract}
This study explores how rural community travel can be an eco-innovation approach to enhance education for sustainable development (ESD) for 2030. The goal of ESD is to enable all-age learners to meet the Sustainable Development Goal 4 (SDG 4); therefore, effective education related to sustainability with respect to the local cultural context has become an urgent issue. Sustainability is not a specific problem, but concerns all living stakeholders, what they think, and how they work for sustainable community development. However, the intrinsic mechanism regarding the psychological process of outside responsible behavior change is still ignored. Therefore, we conducted a case study, wherein we selected a local cocoa cultural industry festival in southern Taiwan to understand the role of sustainability learning to explain this mechanism. The findings revealed that, in general, sustainability learning is a complex and reflexive process interlinked with different learners (stakeholders); it combines individual psychology and behavior, e.g., in positive psychology, learners care about the low-carbon services provided to tourists, and in negative psychology, they care more about finances. Notably, positive psychology affects responsible behavior, thus, promoting the preservation of the living environment. Additionally, we deduced that ESD can be enhanced by involving human senses and positive psychology.
\end{abstract}

Keywords: case study; education for sustainable development; environment protection; environmental psychology; sustainability learning; reflexive process; responsible behavior; rural tourism; sustainable tourism; Taiwan

\section{Introduction}

The concept of sustainability learning is based on different motivations and purposes, so as to find a suitable solution to improve the proposed problems, and then, approach the sustainable development goals (SDGs) proposed by the United Nations (UN) [1]. Based on this perspective, the United Nations Educational, Scientific, and Cultural Organization (UNESCO) [2] defined the goal of education for sustainable development (ESD), proposed for learners of all ages. However, sustainability learning for people of all ages is a challenge [3] because it remains uncertain how a holistic approach can make people resilient learners [4] in sustainable education. Therefore, the UNESCO proposed a roadmap ESD for 2030 [5] (p. 23), which stated that "people living in cities and communities across the world must recognize ESD as a key instrument and lifelong learning opportunity to achieve sustainability at a local level". ESD for 2030 has clearly pointed out that local communities 
can be a key factor for all living people who are learning sustainability with respect to natural resources [6].

Although a local community is suitable for learning sustainability in ESD for 2030, ESD in the community still faces theoretical and practical gaps [7], especially how to play an important role in societal transformation [8] within the environmental, societal-cultural, and economic contexts. Moreover, the local community is a space for people to learn from the environment, following which the environment itself becomes a source of education. However, learners are generally affected by environmentally responsible behaviors [9] and environmental psychology [10]. This may be because, sometimes, environmentally responsible behavior is not derived from individual actions, but from different individuals or local groups; in this case, all workers (or learners) come together to solve environmental problems. In doing so, environmentally responsible behavior is an integrated condition, as explained by Hungerford and Volk [9] (p. 258), who explained that in the Tbilisi conference in 1987, a declaration was made that promoted awareness, sensitivity, attitudes, skills, and participation. Notably, an emergency problem in ESD for 2030 will most likely involve sustainability learning through community partnership [11], while understanding how people's behaviors are affected by environmental psychology. Environmental psychology has been broadly studied from human behavior and well-being to the socio-physical environment [12]. This means that societal awareness reflects community problems in the living environment, in which the quality of life is uncomfortable, unhappy, or unsatisfactory. Furthermore, pollution emissions to the atmosphere cause a greenhouse effect and sudden heavy snow, rain, or fire in mountains. This concerns how the ecological environment has been severely damaged without any opportunity to recuperate.

To synthesize the abovementioned issues in ESD for 2030, we debate that there is a need to develop local communities that can promote sustainability learning that is intrinsic to their environment and place [13]. Travel to rural communities or rural tourism is a way to address this concern [14]. Several reasons underpin the proposed debate, as follows: First, travel activities are fit for learners of all ages. Second, travel considers different environmental stakeholders, involving the demand and supply sides of the travel destination (or community). On the demand side is tourists, whereas service providers on the supply side include local government, community residents, and farmers. Third, travel to rural communities can meet a diverse view of the environmental, social-cultural, and economic contexts. The environment is a rural and natural landscape. The local society contains a varied hierarchy relationship and living culture, such as religions, customs, languages, clothes, and even the local food or cooking style.

Therefore, the critical question is as follows: what is the importance of community travel in sustainability learning. In this study, we selected a local cocoa cultural industry festival that took place in the countryside in southern Taiwan as our case study. A case study is suitable for building theories from an unknown social context, especially appropriate in new topic areas [15]. Notably, our study combined interdisciplinary knowledge, and the examined case contained multiple-level contributions, as follows. First, this study is an industry-university project, which reveals how University Social Responsibility (USR) engages rural community sustainability learning [16]. Second, the case presents a local cultural context for learning sustainable rural development, which maps the concept of shedding within an eco-innovation approach in the tourism field [17]. Third, this case ensured the participation of different stakeholders, with learners of all ages. These included different families seeking free experiences as tourists, students, and teachers with freeof-charge tour guides, local administrators of the Wanlaun Township Office in Pingtung County, small cocoa farmers, the Catholic church, and the community of a traditional Hakka settlement; the study was conducted in a 100-year historical building. Finally, we ensured that the study met the future goals of ESD for 2030. 


\section{Literature Review}

\subsection{Sustainability Learning and ESD for 2030}

Since sustainability learning is another term to explain what we learn from the environment, one important reason is that sustainability has denoted the concept of "related to the social, economic, cultural, ethical, and spiritual domain of our existence" [18] (p. 227). The problem of sustainability is not a single impact factor that affects environmental change [19], but combines various human behaviors related to the society, economy, culture, morals, and our mental state. That is why sustainability learning cannot be explained using one view to fit all things because it consists of a complex network. For example, climate change [20] is not caused by one factor alone; it may be related to $\mathrm{CO}_{2}$ emissions, over-development, and other anthropological activities. However, sustainability learning and its scope and goals do not differ significantly with the Sustainable Development Goal 4 (SDG 4, quality of education) of the United Nations (UN) [1] in ESD for 2030. Notably, ESD for 2030 requires more critical thinking and reflective actions [21]. Therefore, based on the environmental factors, mental state, and learners' behavior, the related literature was reviewed to understand the real meaning of sustainability learning [22].

\subsection{Effects of Environmental Psychology on Sustainability Learning}

The learning environment concerns the living places, natural landscapes, ecological animals, or plants, as well as human historical evidence in the region. In practice, learning environment factors [23] affect the motivation to learn. For example, if the learning place is a school, the learning environment factors are the hardware (buildings, campus, and classroom) and software (learning culture or resources). When the place is fully constructed to offer an effective learning condition, it can increase the motivation to learn. Additionally, previous studies have also discussed aspects of attention [24], beliefs [25], or metaphors [26] during the learning process [27]. The learning environment is an important factor, but the process also plays an important role in successful learning. Learning psychology is a personal factor that is, in turn, affected by intrinsic factors. Therefore, educational psychology [28] has more importance than before.

In the goal of ESD for 2030, education psychology is also of critical importance because sustainability learning belongs to one kind of environmental education, and environmental psychology, thus, attracts more studies in this field [29]. Environmental psychology aims to understand how psychological factors, such as learning sustainable concepts and beliefs, affect people's attitude and behavior toward sustainability [30]. According to this perspective, environmental psychology plays an "essential role in alleviating the impact of climate change" [31] (p. 304). This is why the ESD for 2030 required that the people of all ages should learn and embrace sustainability and its practices. This reasoning is also connected with the environment because a learning environment affects personal learning and intrinsic attitude and imbibes responsible behavior in learners; therefore, the intrinsic psychological process before, during, or after responsible behavior is called pro-environment behavior [32] or positive psychology of sustainability [33].

\subsection{Effects of Sustainability Learning on Environmental Responsible Behavior}

Maiteny [34] conducted a study that revealed an interesting result that people's living experiences and emotions have a strong relationship with pro-environmental behavior change [34]. The word "change" represents how a person's behavior changes from being unresponsible to more responsible, especially when people partake in outdoor activities [35]. This concept is also based on environmental education. Outdoor activities, such as travel or leisure, are generally family activities and have different meaning in environmental education; through these activities, people feel relaxed or happy and their learning motivations are enhanced through people-environment interactions, thus creating better learning outcomes. This can also explain how inner [34] motivation changes people's learning attitude and behavior change. 
Positive psychology [33] improves sustainability learning and cognition, thus enhancing people's positive environmental behavior. This is an intrinsic mechanism that reflects societal transformations [8]. Social transformation may explain why environmental factors are affected by people's thoughts and actions. This may be because people live and work together; thus, people's behavior can determine business benefits and/or result in cost-effective competition. However, this takes a toll on the living environment, resulting in issues, such as pollution and climate change. Today, the global society is concerned about the effective changes in our lives due to unpredictable climate fluctuations and natural hazards. Notably, we have learned much from climate damage, and this, in turn, has affected our behavior, thus promoting societal transformation [36] toward responsible behavior.

Sustainability learning is a way to save our earth, but the extent of effectiveness still depends on how people perceive environmental sustainability [37] with respect to human behavior. Therefore, a meaningful promotion and measurement of pro-environmental behavior [38] has become necessary.

\subsection{Conceptual Framework of Sustainability Learning}

After reviewing the related theories, we developed a conceptual framework to examine how a practical situation may exist in a real context. Figure 1 illustrates the framework below.

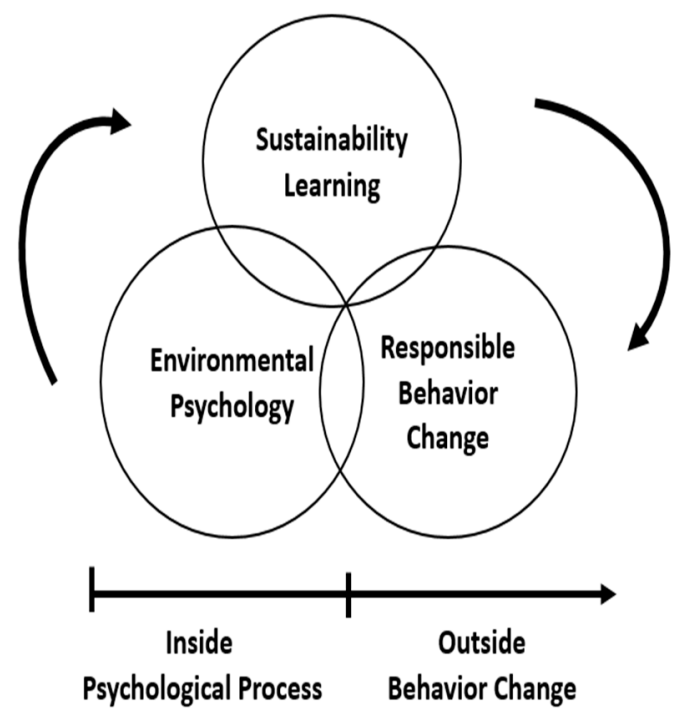

Figure 1. Conceptual framework of sustainability learning, environmental psychology, and responsible behavior.

The framework consisted of three important concepts: sustainability learning, environmental psychology, and responsible behavior change. These three concepts are essential to support people's thinking of sustainability and how they implement related practices via a circulating operation. It is important to determine which operation represents an intrinsic mechanism between people-environment situations. An intrinsic mechanism is segmented into two parts: inside the psychological process and outside behavior change. The functions were examined as follows:

1. Sustainability learning: Understanding the design of a learning activity can support ESD for 2030 [5]. The learning activity should take place for learners of all ages, who are living stakeholders, and travel to the community must be encouraged. Notably, all learners must learn sustainable development within a local context. The local context must be a community that can represent the region's characteristic environmental, sociocultural, and economic circumstances. 
2. Environmental psychology: This concerns understanding what people perceive as environmental learning, and the learning process should be observed or dialogued [29] through the human senses (see, hear, touch, taste, or smell). The reaction of the human sense was used to indicate the people's feelings. These feelings included environmental cognition [39], emotion (happy or unhappy), attention [24], human involvement [40], and motivation [23,41].

3. Responsible behavior change: This point concerns understanding how people engage in personal or group learning activities [42]. The main point in the learning activity may not be an immediate action but concerning a possible or implemented proenvironment behavior within social relationships [32]. Notably, social relationships connect to living stakeholders in responsible behavior. The responsible behavior of stakeholders creates more opportunities to overcome future crises of climate change.

Therefore, the framework plays a vital role in examining the proposed questions, with respect to determining the intrinsic mechanism of sustainability learning in ESD for 2030.

Moreover, the proposed framework is necessary because the rate of climate change has been accelerating; we must learn and correct our actions as soon as possible to mitigate any upcoming negative effects. Thus, this framework provides a way to care for our community and promote ESD for 2030. It is also the goal of Universities' Social Responsibility (USR) [16] to find an optimal method and practice for future social science research [43].

\section{Case Study Methodology}

Yin [44] considered a case study method to discover social science problems. The reason is that a social and cultural context can be best explored in a real setting to deduce an unknown situation. Eisenhardt [15] used a case study to explore social science problems to build a new theory. The case study methodology has also been strongly suggested for application in sustainability research to understand transdisciplinary knowledge of sustainable development [45]. According to this perspective, our study offers transdisciplinary knowledge for various subjects, including sustainability, education, psychology, and human behavior, which is interconnected with different fields and industrial problems; therefore, a case study is suitable to fit the real scenario's exploration.

An empirical study on environmental psychology conducted by Giuliani and Scopelliti [29] indicated that the number of observational studies has grown significantly, therefore, the observational method has become a fundamental method. Observational studies offer a place-specific approach to understand the person-environment relationship in a region. For these reasons, this method was also employed by our study to explore the questions concerning rural community travel. The findings of Giuliani and Scopelliti were as follows [29] (p. 381):

Observational studies on behavior in the environment settings with different functions are included from recreational to service or connecting. Moreover, both natural and built environments (indoor and outdoor) are found. Visitors/customers are the typical population investigated, frequently through field experiments or studies in which observation emerges as a fundamental method for data collection.

Therefore, observational approaches, such as taking photographs and videos are used in participatory learning activities. However, face-to-face gossip must be avoided, and instead, official interviews and news must be used as a source for acquiring data. Notably, in a group activity, it is difficult to conduct interviews due to noise and interference issues, and in general, several other factors may disrupt the interview process. Thus, a case study is an important research approach in the social sciences. In this study, we focused on a qualitative research methodology, and an observational approach was used to collect the personal data before, during, and after the learning activity. The interpretive research approach is suitable for exploring new theory building [15]. The present study seeks to understand the renewed approach in sustainability learning. The study is an interpretive 
case study. The data was collected through local activities and then analyzed to deduce a possible theory. All the observational results were collected, analyzed, and presented in the Result and Discussion section. The steps implemented in our study are explained below in detail:

Step 1: To meet the goal of sustainability learning (ESD for 2030)

The local rural economy generally involves agricultural production and marketing, or the sales of agricultural products to visiting tourists as souvenirs. Therefore, we selected a local cocoa cultural festival in southern Taiwan as our study area. The festival takes places at Wanlaun Township Office in Pingtung County; we selected the data from 2019 until 2021. There was little information available to study the festival in 2019 to 2020. However, in 2021, the Teaching Practice Research Project (Ministry of Education MOE, Taiwan) and USR project of the Meiho University supported this local community festival as an industry-university cooperation. The main aim of the cocoa cultural industry festival is to promote their agricultural products and traditional Hakka culture. The festival not only attracts tourists for consumption (to enhance the rural economy) but also encourages the community's residents to participate in different activities and interact together. This means that all stakeholders, from tourists to administrators of local government and farmers, can understand and explore the local religions and cultural heritage.

Step 2: To collect data from sustainability learning activity in local community

The second step was data collection from the local community festival as a sustainability learning activity. The case study was based on festival activity to collect major and secondary data. The major data were collected using dialogue, photographs, and videos with participant learners. Notably, the learners were from all age groups and included people from the local community, including five administrators of the Wanlaun Township Office, one small cocoa farmer, five students and two teachers as free-charge tour guides, and 65 tourists who were a part of free-charge rural experienced tours. The rural community within a cocoa farm, a Catholic church, and an over 100-year building in the traditional Hakka settlement served as the main location for the festival. The all-age learners were from different families and residents, some of them from northern, central, and southern Taiwan. Their ages ranged from 12 to 75 years, with more females than males. Their marriage status was not recorded. Second, secondary data were collected from the Internet, published books, and newspapers. Finally, the collected data were classified and then stored in an ordered manner. Internal and external validity were used to reduce hidden bias in the observational study. Internal validity was achieved with a participant-observation from one of the authors (observers) to be more subjective, whereas external validity was derived in step 4 with a data triangulation. These data were also arranged by date. Table 1 shows that sustainability learning within a rural community travel program was designed to suit the need and objectives of our study.

Step 3: To analyze data from the cleaned data set

After the data collection process, the collected data were analyzed as follows: The text data were collected in a unified format; the patterns were analyzed using the text mining approach, according to theories related to sustainability learning [41,45], local community [11] and cultural experiences. Therefore, texts were searched for the keywords "learning", "community", "experience", and "culture", along with specific descriptions. In cases where the interview approach was difficult to use, we used recording archives collected from video files. Additionally, voice data were transferred to transcripts, and then, analyzed using a text mining approach. Most of the recorded data were represented by photographic pictures. These data should be segmented as meaning behavior through activities such as human sense in seeing, hearing, touching, tasting, and smelling behavior. This was estimated by a domain expert, participant (one of the authors), and the activity's host, such as the administrators of the Wanlaun Township Office. The categories used for analyzing data were the sentiments from tourists' faces and behaviors, including emotions (smile, happy or unhappy), attention [24], and activity involvement [40]. 
Table 1. Sustainability learning in a short-term rural community travel program.

\begin{tabular}{|c|c|c|c|}
\hline Destination & $\begin{array}{c}\text { Time of Stay } \\
\text { (min) }\end{array}$ & Main Learning Purpose & Data Collection \\
\hline $\begin{array}{l}\text { Wanjin } \\
\text { Basilica }\end{array}$ & 50 & $\begin{array}{l}\text { The Wanjin Basilica is the } \\
\text { oldest Catholic church in } \\
\text { Taiwan. The learning objective } \\
\text { was to understand how the } \\
\text { Wanjin Basilica assists local } \\
\text { religious development. }\end{array}$ & $\begin{array}{c}\text { Dialogues with } 20 \text { tourists, } \\
100 \text { photographs taken, and } \\
10 \text { videos }\end{array}$ \\
\hline $\begin{array}{l}\text { Wugoshuei } \\
\text { Community }\end{array}$ & 50 & $\begin{array}{l}\text { The community is the biggest } \\
\text { traditional Hakka cultural } \\
\text { settlement in the country. The } \\
\text { learning objective was to } \\
\text { understand how ethnic } \\
\text { settlements can add value to } \\
\text { eco-tourism in a place and } \\
\text { promote cultural and heritage } \\
\text { conservation. }\end{array}$ & $\begin{array}{c}\text { Dialogues with } 30 \text { tourists, } \\
138 \text { photographs taken, and } \\
10 \text { videos }\end{array}$ \\
\hline $\begin{array}{c}\text { DiRaja } \\
\text { Chocolate }\end{array}$ & 50 & $\begin{array}{l}\text { Wanlaun Township has } \\
\text { become an important place for } \\
\text { cocoa cultivation. The learning } \\
\text { objective was to visit a farm } \\
\text { that provides low-carbon } \\
\text { service for tourists during their } \\
\text { "experience" process. }\end{array}$ & $\begin{array}{c}\text { Dialogues with } 15 \text { tourists, } \\
217 \text { photographs taken, and } \\
12 \text { videos }\end{array}$ \\
\hline
\end{tabular}

Step 4: Reliability and validity of analyzed process were determined

In a case study, Meyer [46] denoted the reliability and validity of the applied criteria in the examined method. Therefore, in our study, internal and external validity was used for the examined data. The internal data criteria were measured and a positive relationship with the local community festivals was connected with sustainability learning activities. In terms of external validity, the results showed that the study can be extended from the local to the national level (compared with Wamsler's work [8] published in 2020).

For the consistency of the examined data, the concept of reliability was used in this qualitative study. A study can be considered reliable if its findings can be found again; reliability can also be determined through the triangulation method with data, investigator, theory, and methodological diversity. Merriam [47] explained that the reliability of qualitative studies for education is "concerned with the question of the extent to which one's findings will be found again". After the double checks, it was determined that the findings in the present study could be found again in other rural communities $[8,11,17]$. Therefore, we confirmed that the examined data was consistent with the current research method. On the other hand, Oliver-Hoyo and Allen [48] used triangulation methods to measure the reliability of qualitative educational research. Therefore, the present study followed the process of assessing the reliability of the analyzed data through triangulation. Table 1 shows the collected data information. Firstly, regarding data triangulation, we served three groups at different times, spaces, and people. Secondly, regarding investigator triangulation, we used the data from different participants, such as administrators, USR teachers, and one of the authors. Thirdly, regarding theory triangulation, we used different theoretical schemes to enrich the studied questions, which helped us understand the gap between theory and real circumstances. Finally, regarding methodological triangulation, was methodological triangulation, we used different data-collection methods, such as observation, conversation, photography, video, research notes, and learning activities. 


\section{Result and Discussion}

\subsection{Effect of Environmental Psychology on Sustainability Learning}

Sustainability learning is a specific learning process in a natural environment, and therefore, adaptive management, participatory processes, and small-sized samples are necessary for such studies [49]. Notably, our aim was to assist learners of all ages to understand the learning process pertaining to sustainability in a small region. The travel program was designed by the Wanlaun Township Office and one of the authors (at the tourism department of the Meiho University, Taiwan). We recruited 65 tourists for freecharge tours; these tourists were arranged into three groups. Each group visited three destinations from 1 October 2021 to 2 October 2021, separately. In total, the three groups captured many photos and videos. Before and after the tour, all team members discussed the advantages and disadvantages of the learning activities. Therefore, two photos were selected to explain the effects of environmental psychology on sustainability learning. The observational results are shown in Figure 2.

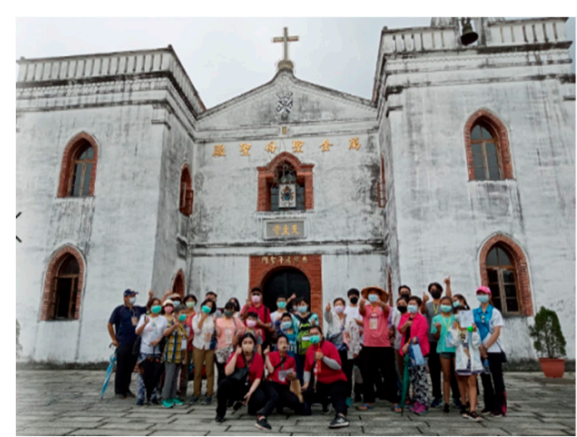

(a)

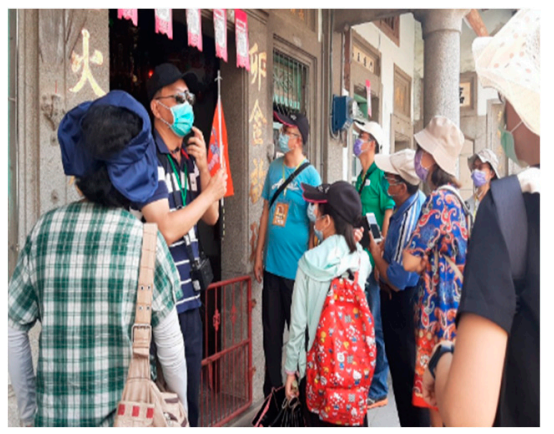

(b)

Figure 2. Sustainability learning activity through rural community travel: (a) Wanjin Basilica, the oldest Catholic church in Taiwan; and (b) The biggest traditional Hakka cultural settlement in Taiwan. All the learners paid attention and listened to how sustainable development can be a part of community and human involvement. One of authors was the tour guide (center of photo (b)).

Before the tour, the administrators of the Wanlaun Township Office stated that their main objectives were for tourists to not only buy their agricultural products but also learn from their community culture; the ideology being if the tourists liked the local culture, they would return again. Therefore, during the tour of the first and second destinations (Wanjin Basilica and Wugoshuei Community), the tour guides (one of the authors and voluntarily students) took efforts to interpret the heritage of the buildings through meaningful stories with historical evidence. Notably, we observed that all the learners learned about sustainability because they paid attention, as seen in Figure $2 b$ where tourists' behavior was focused on seeing the tour guides and also because they felt involved in the environment. Therefore, observational and interview data indicated that sustainability learning took place. One of the tourists said the following:

I knew that the residents living in the Wanlaun Township followed Buddhism and Taoism, but an interesting thing here (Wanjin village) is that the residents changed their religion to become Catholic. I really did not know that Wanjin Basilica was the oldest Catholic church in Taiwan. The church was built using local black soil, carbon, and honey. All building materials were natural. This is why this church has a critical value today. I thought that the Wanjin Basilica played an important role in rural sustainable development, because for a long time, it was not acceptable for outsiders to visit the church, but the missionaries were patient and cared for poor people (children, older, and women), and then can stay. I believe that the Wanjin Basilica has become a social-cultural center in the minds of the local residents. They have love and tolerance, want to support 
the sustainable development of their community, and engage with people of different religions and cultures, while embracing environmental sustainability. (Male, 55 years old, retired tour guide)

According to the selected photos, conversations recorded, and research notes from the three visits, the visit process has involved tourists in sustainability learning. The evidence portrayed that environmental psychology has positive effects on sustainability learning. This was because the results indicated that all the learners fit five criteria: environmental cognition, emotion, attention, human involvement, and motivation. Therefore, the goal of sustainability learning was successfully achieved.

During the three tours, the tour guides observed the learners' ability to pay attention [24]. If the tourists were bored, they did not look at the tour guides, whereas when interpreting points on the sustainable story to explain the local culture or architecture, they maintained good eye contact with the tour guides. Thus, we could deduce that environmental factors enhance tourists' psychology toward environmental involvement [40]. That was to explain why "this trip really changed me" [50]. This denoted a self-change and indicated an intrinsic mechanism for mapping changing motivation [23,41]. Motivation is a psychological process involving personal experiences to make decisions. Moreover, motivation is also related to environmental cognition [39] and environmental emotions [51]. Notably, the above findings are strongly supported by Giuliani and Scopelliti [29]. In other words, the observation is an empirical approach for understanding tourist's behaviors. Through human senses (sight, hearing, touch, taste, or smell) an intrinsic environmental psychology $[10,12,29-31]$ thus can be clearly to explore. We found that when tourists interacted with tour guides, they could talk more about the oldest and largest architectures. Tourists' sustainable learning through environmental psychology can, thus, explain what they have understood and how they do after visiting. Notably, in this case, the buildings themselves were the storytellers, engaging in human interaction through human senses: seeing, hearing, and touching, without causing any damage to the Catholic church and the traditional Hakka cultural settlement. Therefore, we summarize the major effects of psychological factors on sustainability learning in Table 2.

Table 2. The major effects of psychological factors on sustainability learning.

\begin{tabular}{ll}
\hline $\begin{array}{c}\text { Psychological } \\
\text { Factor }\end{array}$ & \multicolumn{1}{c}{ Sustainability Learning from Evidence } \\
\hline $\begin{array}{c}\text { Environmental } \\
\text { cognition [39] }\end{array}$ & $\begin{array}{l}\text { Participants felt the rural cultural experiences were meaningful. In the } \\
\text { three places, participants identified differences that demonstrated } \\
\text { cognition [39]. For example, learners understood that the historical } \\
\text { building is important and determined that it should be protected. (Stated } \\
\text { by a 65-year-old mother) }\end{array}$ \\
\hline & $\begin{array}{l}\text { Participants showed emotions on their face and in their behavior. One } \\
\text { family said that "we are very happy because we never knew why our } \\
\text { community had those interesting places, even though we live close to them. }\end{array}$ \\
& $\begin{array}{l}\text { We appreciate your interpretation on this tour" and "We are willing to } \\
\text { attend the next tour this afternoon. It makes us very relaxed when the tour } \\
\text { takes us on a slow walk. (Stated by a female; the peoples' ages are 12, 24, } \\
\text { 30, and 70 years old) }\end{array}$ \\
\hline Attention [24] & $\begin{array}{l}\text { Participants' attention is focused on eye contact. On all three tours, all the } \\
\text { attendees paid attention to the interpretation. Figure 2b showed the } \\
\text { attention of attendees. All the attendees were following tour guide and } \\
\text { their directions. One crucial piece of evidence is that no one leaves the tour } \\
\text { early and many attendees even participated twice. (Stated by two females; } \\
\text { the administrators of the Wanlaun Township Office) }\end{array}$ \\
\hline
\end{tabular}


Table 2. Cont.

\begin{tabular}{cl}
\hline $\begin{array}{c}\text { Psychological } \\
\text { Factor }\end{array}$ & \multicolumn{1}{c}{ Sustainability Learning from Evidence } \\
\hline $\begin{array}{c}\text { Human } \\
\text { involvement [40] }\end{array}$ & $\begin{array}{l}\text { A place enhances human involvement. Outdoor activity has played an } \\
\text { important role in this way. One participant said that "we are residents but } \\
\text { we did not know the story of the Church, nor what the cocoa festival } \\
\text { activity is, but through your interpreting I now know what cultural } \\
\text { heritage is and why agricultural culture can be an experience economy. } \\
\text { (Stated by a couple; aged 25 and 26 years old) }\end{array}$ \\
\hline & $\begin{array}{l}\text { Motivation, in this case, was shown in various. One way is that all the } \\
\text { participants are very happy. Moreover, 99\% responded that they willing } \\
\text { attend again (as stated by the administrators of the Wanlaun Township }\end{array}$ \\
& $\begin{array}{l}\text { Office). Additionally, motivation to support small businesses can be shown } \\
\text { through increased orders for a small cocoa farm after the tour (as stated by } \\
\text { the cocoa farm owner). The final way is reflected in the environmental } \\
\text { education; all attendees said to the researcher that it was a wonderful } \\
\text { learning activity. One group stated, "We came from the center of Taiwan } \\
\text { (Taichung City), and we did not know why a famous place has different } \\
\text { and interesting activities. We learned a lot of information from you and } \\
\text { thank you very much". (Stated by three elderly females aged 75, 78, and } \\
\text { 82 years old) }\end{array}$ \\
\hline Motivation [23,41]
\end{tabular}

\subsection{Effect of Sustainability Learning on Responsible Behavior Change}

Environmental behavior is usually defined by responsible behavior. If people work or live in an environmentally friendly way, it is termed pro-environmental behavior [38]. If not, this is termed environmental damage [52]. The following photos show the results which have shown a pro-environment approach in the working environment. Figure 3 shows tourists' experiences and photos.

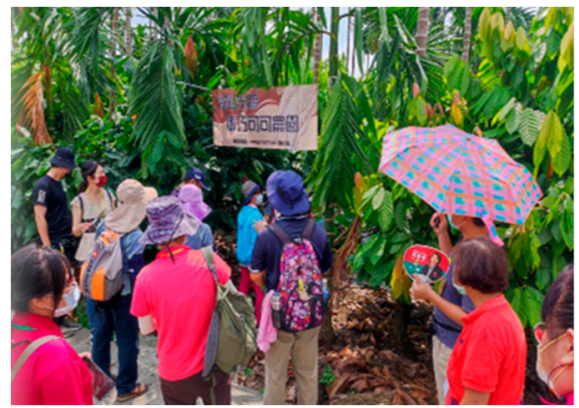

(a)

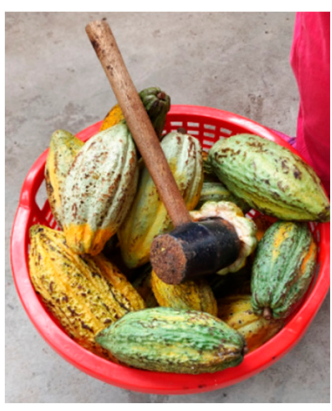

(b)

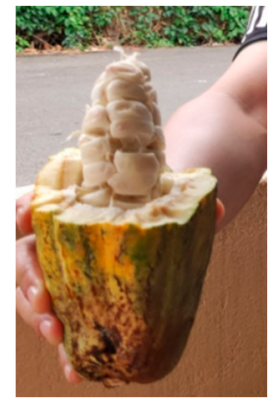

(c)

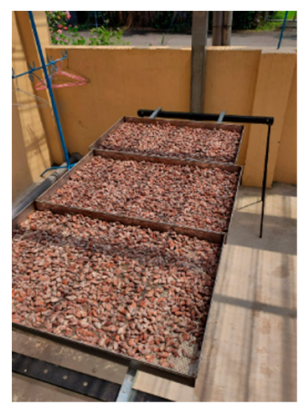

(d)

Figure 3. Tour of a cocoa farm by a farmer who provided low-carbon service. DiRaja Chocolate is the brand name of small cocoa farmer in Taiwan. They have received several certifications labeling them as non-toxic chocolate masters who have adopted friendly environment farming conditions. The small cocoa farmer provided tourists sensory services to help them appreciate the cocoa produce. This fit the goal of sustainability learning activity through rural community travel. (a) The cocoa farm visited by the tourists; (b) Cocoa fruits with hammer used to peel the fruit; (c) Opened cocoa fruit in tourist's hand; and (d) Cocoa beans dried in the sun.

During the travel program, the cocoa cultural industry created a knowledge value for tourists. In the Wanlaun Township, most residents were life-long farmers. Older farmers used pesticides due to the traditional but effective approach for farming. However, today, environmental conservation laws do not allow the continued use of toxic pesticides. Therefore, non-toxic and environmentally friendly farming conditions have been promoted and broadly applied in Taiwan. The selected photos portray that the small cocoa farmer followed an environmentally friendly approach to help preserve the land and ensure human health and well-being. The small cocoa farmer provided a non-toxic farming approach, 
which has delivered the concept of a low-carbon supply chain and operations [53]. Notably, the small cocoa farmers, who represented a small enterprise, were involved in the actual process of cocoa farming, product design and production, packaging, and marketing. The farmers used local resources and recycled agricultural products, e.g., cocoa crust and nibs recycling. Therefore, the farm achieved the goal of sustainability learning. The owner of the small cocoa farm expressed the following:

I am Malaysian, and I was married in Taiwan ten years ago. Because my husband's father and mother were older than before, we returned here for cocoa farming. I knew the importance and value of cocoa because in my home country, cocoa was an agriculture produce. There are many nutritional elements in and specific benefits from cocoa, but not many people know about it. I said to my husband, "I am willing to return home", even though it was a countryside and not convenient like northern Taiwan. Therefore, I decided to return here, but my husband still works in northern Taiwan, in Taoyuan City. Why did I use an environment-friendly approach? I thought that non-toxic farming or not using modern pesticides was difficult, but I realized that I should protect our environment, and ensure the safety of all my customers and myself. Although, non-toxic farming was hard work, I must pay more effort to weed something I did not want, because it has more benefits for me and my customers. One concern was about my health: because I am so young, I did not want to die because I used pesticides. Another concern was for my customers. Therefore, I farmed and worked for a healthy business; there was no point in working while compromising one's health; that was not my style. Therefore, I combined many sources and concepts from my home country, and developed a new brand of chocolate to serve this big marketplace, but only one thing was that I did not know how to offer my place for sustainability learning. Fortunately, the cocoa cultural industry festival gave me the opportunity to show my farm. In this year, 2021, my farm and workroom have initiated tours to provide farm education and experience activities. It was interesting not only to teach students and tourists but also to learn a lot from our guests". (Female, 45 years old, owner of a small cocoa farm)

Low-carbon services have shown that environmental psychology has experienced and transferred to responsible behavior, thus, promoting societal transformation [8]. This transformation engages the learners to imbibe a more pro-environmental behavior $[38,54]$. Pro-environmental behavior is usually affected by managing environmental change [55]. Thus, travel to rural communities can affect environment change; therefore, based on the observational results, we found the sustainability learning was applicable for not only the tourists but also the service provider. By analyzing the owners' and experienced tourists' responses, we could deduce that sustainability learning is a knowledge-transfer process [56]. As shown in Figure 3, the owner of the small cocoa farm shared information on environmentally friendly farming behaviors and related knowledge with tourists. The process of protecting the environment was transferred from the small cocoa farmers to the tourists. Therefore, the concept of environmental education [57] was successfully provided to the customers through the environmentally responsible behaviors of the service providers, such as the small cocoa farm owners. The success of the sustainability learning can be backed by evidence. This evidence manifested in five forms, namely, environmental cognition, emotion, attention, human involvement, and motivation, along with the tourists' consumption. The participants created several chocolates during the activity, and the chocolate sold out. Moreover, there was a lot of friendly feedback from the local government-Wanlaun Township Office. Compared with the same activity in 2019 to 2020, 2021 was more successful following the industry-university cooperation with the tourism department of Meiho University. This also showed that the behavior of environmental conservation can be learned as an example of rural community travel. Therefore, we summarize the responsible behavior change in Table 3. 
Table 3. The sustainability learning effects on responsible behavior change.

\begin{tabular}{|c|c|}
\hline $\begin{array}{l}\text { Community's } \\
\text { Stakeholders }\end{array}$ & The Responsible Behavior Change \\
\hline $\begin{array}{l}\text { The service } \\
\text { providers }\end{array}$ & $\begin{array}{l}\text { 1. Local government-Wanlaun Township Office played an important } \\
\text { role in environmental education. A local festival can effectively } \\
\text { deliver a meaningful program for social learning. The local } \\
\text { government is also a sustainability learner who learned how to } \\
\text { organize a valuable activity for environmental conservation. } \\
\text { 2. A small farmer (or many farmers) who directly impact environmental } \\
\text { conservation. The farming approach and agricultural products are all } \\
\text { concerned about how they may impact the environment positively or } \\
\text { negatively. When a pro-environment behavior happens, it thus } \\
\text { provides a familiar story for tourists to experience. There are also } \\
\text { benefits from selling products, making for a healthy working } \\
\text { environment for farmers themselves. Therefore, a farmer's story can } \\
\text { change provide knowledge to consumers at any time. }\end{array}$ \\
\hline The participants & $\begin{array}{l}\text { 1. The children learn responsible behavior from family education travel } \\
\text { together. } \\
\text { 2. The younger people learn sustainability knowledge from schools but } \\
\text { practical authenticity from the real world. After seeing and touching, } \\
\text { they change behavior to save water, energy, or care about cultural } \\
\text { heritage. } \\
\text { The middle-aged persons on a different societal level have a } \\
\text { considerable influence. When they learn from the rural community, } \\
\text { they can reconstruct their thinking about the environment and } \\
\text { influence each other. } \\
\text { The elderly can find a good place for an extended stay. A health trip } \\
\text { can improve people's well-being, change behavior, and finally age in } \\
\text { place. }\end{array}$ \\
\hline The residents & $\begin{array}{l}\text { A resident can be a protector or spoiler in sustainable development. After } \\
\text { the festival, many residents recognized that "my place is a good place". } \\
\text { Before, they did not feel the specific value of the traditional language and } \\
\text { cultural buildings, but they changed attitudes and behavior after the } \\
\text { activity. Some even cared about the river or brook and appealed for } \\
\text { protective actions. }\end{array}$ \\
\hline
\end{tabular}

\subsection{Importance of Rural Community Travel in Sustainability Learning}

To synthesize the above findings and discussion, we noted that rural community travel can be a way for sustainability learning [58]. Figure 4 portrays a new theoretical contribution constructed in our case study [59].

The new theory is termed sustainability learning supply chain, which integrates the concept of sustainability learning for not only the tourists or customers but also the service providers. In our study, we used rural community travel as an intervention approach for understanding sustainability learning. Notably, the local community plays a vital role in engaging the tourists and providing an interactive environmental, sociocultural, and economic context to the visitors [13], with the aim of sustainable community development. The different parameters provided in Figure 4 can be explained as follows:

1. Destination: The destination plays a central role in the entire supply chain, connects with upstream and downstream learning activities, and creates a community with respect to the sustainable development and environmental education of a local place. As a sustainable tourism [60], the travel process really enhanced sustainability learning because it provided an environmental, sociocultural, and economic context that was immersive for learners of all ages. Therefore, the rural community supported the sustainability learning goal of ESD for 2030.

2. Supply side: The scope of this parameter is to promote business-to-business (B2B) sustainability learning, while ensuring the cooperation of all local suppliers to provide 
cultural ecosystem services [61]. Cultural ecosystem services are service providers that should consider what low-carbon services or products can be provided to the customers. The learning objective in this area concerns environmental conservation and corporate social responsibility [62]. The major reason for this is that, generally, in a rural setting, the supply side mainly consists more small and medium-sized enterprises. These enterprises are the sources or materials of agricultural food production, and their products are more concerned about human health and food safety.

3. Demand side: The scope of this parameter is to promote business-to-customer (B2C) sustainability learning, which focuses on the tourist's responsible behavior. Proenvironmental behavior should be fostered because most tourists are not only consumers or end users but also key stakeholders in sustainability. A major reason is that tourists bring or create garbage and sometimes waste natural resources, such as water, energy, or food. Notably, if human behavior [36,37] cannot transition toward responsibility, the goal of ESD for 2030 will be difficult to achieve.

\section{Supply side $\longrightarrow$ Destination $\longrightarrow$ Demand side}

\section{Sustainable Development}

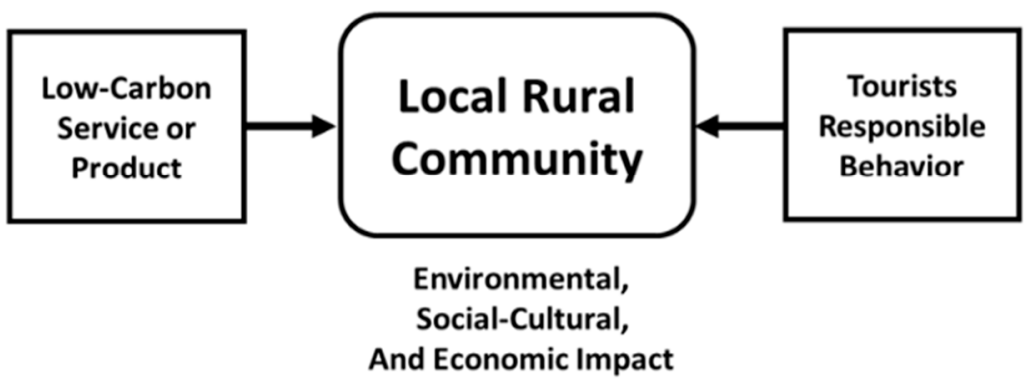

\begin{tabular}{|l|l|} 
— B2B Sustainability Learning & B2C Sustainability Learning \\
\hline
\end{tabular}

Figure 4. New theory indicating the sustainability learning supply chain, as constructed in our case study. Abbreviations: B2B, business to business; B2C, business to customer.

In our study, we have tried to make a theoretical contribution through a case study, which reveals a community-driven model [63] on sustainable development in rural areas. Our study revealed a significant finding with respect to rural community travel, indicating a complex and reflective process that involved environmental psychology and responsible behavior. Notably, this perspective has not been explored effectively in previous studies. This is because when we learn about sustainability and the factors that drive or affect it, such as climate change, we tend to forget why we learned it in the first place. Is it really all about climate change alone?

\section{Conclusions and Limitations}

Since climate change has increasingly threatened people's health and well-being, our study portrays how local communities can assist people in learning sustainability locally [13]. Rural community travel serves learners of all ages to enhance their experience of learning about sustainable development. Moreover, our findings unfolded an intrinsic mechanism that operated when people learned in the natural landscape and rural society. Notably, we were able to understand how a community plays an important role in responding to ESD for 2030 and determine how communities make rural tourism a sustainable strategy [64] for environment conservation. This sustainable strategy uses rural resources to enhance community behavior and sustainable rural development [65]. Therefore, rural communities can become an environmental educational place. Notably, rural places 
are suitable for sustainability learning and are becoming a useful tool to implement the eco-innovation marketing approach [66].

\subsection{Educational and Managerial Implications}

Two important implications were deduced from our case study: educational and managerial implications. First, sustainability learning was not considered in a holistic framework. This was because most environmental education focuses on theoretical education, and practical learning is available only for young students. Thus, most adult environmental education is ignored. Adult environmental education involves not only university students but also people who have left/passed universities. Therefore, it is best for such studies to be inclusive of all ages and gender. For this reason, a more holistic framework should be considered, such as the concept of green supply chain management [67]. Green supply chain management aims to increase the sustainable development value [68] for all stakeholders, including the learners, who must be introduced to sustainability learning that is enhanced, engaging, and implemented with good management.

Therefore, educational implications are involved in green supply chain management to create awareness and promote the concept of environmental conservation through cognition and the concept of eco-system knowledge creation [69]. Ecosystem knowledge is created to promote learning about the living environment. However, the living environment has been ignored in the creation of ecosystem knowledge. One of the important reasons is that an intrinsic mechanism cannot generally be seen and touched, but it actually plays a specific role in environmental education. We thought that the reason for this limitation may be the learning implications behind a psychological process, such as cognition, emotion, and motivation. For example, if a learner does like outdoor learning activity, the learner's senses must be used to provide a more comprehensive and engaging learning experience. Notably, managerial implications and educational implications strongly influence environmental psychology and responsible behavior.

\subsection{Methodology Limitations and Suggestions for Future Research}

This study contributes to the field of sustainability learning [6,22,41,45], but it has some practical limitations. First, the study focused on the response of an effective approach for sustainability learning in ESD for 2030. Although rural community travel has been found to be suitable for learners of all ages, it unraveled only one of the many applicable learning methods. Second, our case study involved Taiwan's rural community, which is located in Southeast Asia, and the research results cannot fit other situations found worldwide. Third, our study method required 2 years of preparation to collect data, and the study time and budget were limited. Moreover, we used a rigorous triangulation method to ensure data reliability and validity, the observational study is still subjective. Therefore, we encourage more future works to explore the related research topics on environmental psychology, such as the psychological process of how to work and interact with learners of all ages. In particular, the topic of responsible behavior is more concerned about how the low-carbon service can be explored as a traveling product. Additionally, because we analyzed the importance of responsible behavior education not only for students but also for all living residents and tourists, this study should be considered an opportunity to learn and critically analyze the viable steps for a sustainable future. We also encourage scholars to investigate psychological factors such as sustainability happiness [70] and develop more conceptual frameworks from step-by-step case studies [71].

Author Contributions: Supervision, C.-C.T.; Formal analysis, F.-H.C.; Software of data analysis, P.-Y.C.; Conceptualization, writing — original draft, writing—review \& editing, W.-S.L. All authors have read and agreed to the published version of the manuscript.

Funding: This research was funded by Ministry of Education Republic of China (MOE, Taiwan), grant number PHE1090156, the 2020 Project of MOE Teaching Practice Research Program.

Institutional Review Board Statement: Not applicable. 
Informed Consent Statement: Informed consent was obtained from all subjects involved in the study.

Data Availability Statement: Not applicable.

Acknowledgments: We would like to thank the reviewers for their valuable comments and efforts. We would especially like to thank the Wanlaun Township Office and students and faculties at the Department of Tourism of Meiho University, for their valuable collaboration and assistances during the project each practical stage.

Conflicts of Interest: The author declares no conflict of interest.

\section{References}

1. UN (United Nations). The Sustainable Development Goals Report 2020. Available online: https://sdgs.un.org/publications/ sustainable-development-goals-report-2020-24686 (accessed on 1 January 2022).

2. UNESCO (United Nations Educational, Scientific and Cultural Organization). Education for Sustainable Development. Available online: https:/ / en.unesco.org/themes/education-sustainable-development (accessed on 1 January 2022).

3. Henry, A.D. The Challenge of Learning for Sustainability: A Prolegomenon to Theory. Hum. Ecol. Rev. 2009, 16, 131-140.

4. Sterling, S. Learning for Resilience, or the Resilient Learner? Towards a Necessary Reconciliation in a Paradigm of Sustainable Education. Environ. Educ. Res. 2010, 16, 511-528. [CrossRef]

5. UNESCO (United Nations Educational). Education for Sustainable Development: A Roadmap (ESD for 2030). Available online: https:/ / unesdoc.unesco.org/ark:/48223/pf0000374802 (accessed on 2 January 2022).

6. Tàbara, J.D.; Pahl-Wostl, C. Sustainability Learning Natural Resource Use and Management. Ecol. Soc. 2007, 12, 1-15. Available online: http:/ / www.ecologyandsociety.org/vol12/iss2/art3/ (accessed on 2 January 2022).

7. Kopnina, H.; Meijers, F. Education for Sustainable Development (ESD): Exploring Theoretical and Practical Challenges. Int. J. Sustain. High. Educ. 2014, 15, 188-207. [CrossRef]

8. Wamsler, C. Education for Sustainability: Fostering a More Conscious Society and Transformation Towards Sustainability. Int. J. Sustain. High. Educ. 2020, 21, 112-130. [CrossRef]

9. Hungerford, H.R.; Volk, T.L. Changing Learner Behavior Through Environmental Education. J. Environ. Educ. 1990, $21,8-21$. [CrossRef]

10. Stokols, D. Environmental Psychology. Annu. Rev. Psychol. 1978, 29, 253-295. [CrossRef]

11. Allen-Gil, S.; Walker, L.; Thomas, G.; Shevory, T.; Elan, S. Forming a Community Partnership to Enhance Education in sustainability. Int. J. Sustain. High. Educ. 2005, 6, 392-402. [CrossRef]

12. Mannarini, T.; Talo, C.; Ntzani, E.; Kritikou, M.; Majem, L.S.; Salvatore, S.; Brandi, M.L. Sense of Community and The Perception of the Socio-Physical Environment: A Comparison Between Urban Centers of Different Sizes Across Europe. Soc. Indic. Res. 2018, 137, 965-977. [CrossRef]

13. Alvarez, A.; Rogers, J. Going “Out There”: Learning About Sustainability in Place. Int. J. Sustain. High. Educ. 2006, 7, 176-188. [CrossRef]

14. An, W.; Alarcón, S. How Can Rural Tourism Be Sustainable? A Systematic Review. Sustainability 2020, 12, 7758. [CrossRef]

15. Eisenhardt, K.M. Building Theories from Case Study Research. Acad. Manage. Rev. 1989, 14, 532-550. [CrossRef]

16. Giuffré, L.; Ratto, S.E. A New Paradigm in Higher Education: University Social Responsibility (USR). J. Educ. Hum. Dev. 2014, 3, 231-238.

17. Alonso-Almeida, M.D.M.; Rocafort, A.; Borrajo, F. Shedding Light on Eco-Innovation in Tourism: A Critical Analysis. Sustainability 2016, 8, 1262. [CrossRef]

18. Wals, A.E.; Jickling, B. "Sustainability" in Higher Education: From Doublethink and Newspeak to Critical Thinking and Meaningful Learning. Int. J. Sustain. High. Educ. 2002, 3, 221-232. [CrossRef]

19. Vitousek, P.M. Global Environmental Change: An Introduction. Annu. Rev. Ecol. Syst. 1992, 23, 1-14. [CrossRef]

20. Thuiller, W. Climate Change and the Ecologist. Nature 2007, 448, 550-552. [CrossRef]

21. Kopnina, H. Education for The Future? Critical Evaluation of Education for Sustainable Development Goals. J. Environ. Educ. 2020, 51, 280-291. [CrossRef]

22. Burns, H. Meaningful Sustainability Learning: A Study of Sustainability Pedagogy in Two University Courses. Int. J. Teach. Learn. High. Educ. 2013, 25, 166-175.

23. Hanrahan, M. The Effect of Learning Environment Factors on Students' Motivation and Learning. Int. J. Sci. Educ. 1998, 20, 737-753. [CrossRef]

24. Kruschke, J.K. Attention in Learning. Curr. Dir. Psychol. Sci. 2003, 12, 171-175. [CrossRef]

25. Reber, R.; Greifeneder, R. Processing Fluency in Education: How Metacognitive Feelings Shape Learning, Belief Formation, and Affect. Educ. Psychol. 2017, 52, 84-103. [CrossRef]

26. Hager, P.; Hodkinson, P. Moving Beyond the Metaphor of Transfer of Learning. Br. Educ. Res. J. 2009, 35, 619-638. [CrossRef]

27. Vermunt, J.D. The Regulation of Constructive Learning Processes. Br. J. Educ. Psychol. 1998, 68, 149-171. [CrossRef]

28. Thorndike, E.L. The Contribution of Psychology to Education. J. Educ. Psychol. 1910, 1, 5. [CrossRef] 
29. Giuliani, M.V.; Scopelliti, M. Empirical Research in Environmental Psychology: Past, Present, and Future. J. Environ. Psychol. 2009, 29, 375-386. [CrossRef]

30. Jones, A. The Psychology of Sustainability: What Planners Can Learn from Attitude Research. J. Plan. Educ. Res. 1996, 16, 56-65. [CrossRef]

31. Pelletier, L.G.; Lavergne, K.J.; Sharp, E.C. Environmental Psychology and Sustainability: Comments on Topics Important for Our Future. Can. Psychol. 2008, 49, 304. [CrossRef]

32. Videras, J.; Owen, A.L.; Conover, E.; Wu, S. The Influence of Social Relationships on Pro-Environment Behaviors. J. Environ. Econ. Manag. 2012, 63, 35-50. [CrossRef]

33. Verdugo, V.C. The Positive Psychology of Sustainability. Environ. Dev. Sustain. 2012, 14, 651-666. [CrossRef]

34. Maiteny, P.T. Mind in the Gap: Summary of Research Exploring 'Inner' Influences on Pro-Sustainability Learning and Behaviour. Environ. Educ. Res. 2002, 8, 299-306. [CrossRef]

35. Palmberg, I.E.; Kuru, J. Outdoor Activities as A Basis for Environmental Responsibility. J. Environ. Educ. 2000, 31, 32-36. [CrossRef]

36. Alvord, S.H.; Brown, L.D.; Letts, C.W. Social Entrepreneurship and Societal Transformation: An Exploratory Study. J. Appl. Behav. Sci. 2004, 40, 260-282. [CrossRef]

37. Vlek, C.; Steg, L. Human Behavior and Environmental Sustainability: Problems, Driving Forces, and Research Topics. J. Soc. Issues 2007, 63, 1-19. [CrossRef]

38. Lange, F.; Dewitte, S. Measuring Pro-Environmental Behavior: Review and Recommendations. J. Environ. Psychol. 2019, 63, 92-100. [CrossRef]

39. Evans, G.W. Environmental Cognition. Psychol. Bull. 1980, 88, 259. [CrossRef]

40. Spagnolli, A.; Gamberini, L. A Place for Presence. Understanding the Human Involvement in Mediated Interactive Environments. PsychNol. J. 2005, 3, 6-15.

41. Hansmann, R. "Sustainability Learning": An Introduction to the Concept and Its Motivational Aspects. Sustainability 2010, 2, 2873-2897. [CrossRef]

42. Helen, B. An Approach to Learning Activity Design. In Rethinking Pedagogy for a Digital Age; Routledge Publications: Abingdonon-Thames, UK, 2007; pp. 46-60.

43. Bhattacherjee, A. Social Science Research: Principles, Methods, and Practices; Textbooks Collection 3; University of South Florida: Tampa, FL, USA, 2012; Available online: http:/ /scholarcommons.usf.edu/oa_textbooks/3 (accessed on 3 January 2022).

44. Yin, R.K. Case Study Research: Design and Methods, 3rd ed.; Sage Publications: Newbury Park, CA, USA, 2003.

45. Scholz, R.W.; Lang, D.J.; Wiek, A.; Walter, A.I.; Stauffacher, M. Transdisciplinary Case Studies as A Means of Sustainability Learning: Historical Framework and Theory. Int. J. Sustain. High. Educ. 2006, 7, 226-251. [CrossRef]

46. Meyer, C.B. A Case in Case Study Methodology. Field Methods 2001, 13, 329-352. [CrossRef]

47. Merriam, S.B. What Can You Tell from an N of I?: Issues of Validity and Reliability in Qualitative Research. PAACE J. Lifelong Learn. 1995, 4, 51-60.

48. Oliver-Hoyo, M.; Allen, D. The Use of Triangulation Methods in Qualitative Educational Research. J. Coll. Sci. Teach. 2006, 35, $42-47$.

49. Fujitani, M.; McFall, A.; Randler, C.; Arlinghaus, R. Participatory Adaptive Management Leads to Environmental Learning Outcomes Extending Beyond the Sphere of Science. Sci. Adv. 2017, 3, e1602516. [CrossRef] [PubMed]

50. Noy, C. This Trip Really Changed Me: Backpackers' Narratives of Self-Change. Ann. Tour. Res. 2004, 31, 78-102. [CrossRef]

51. Vining, J. Environmental Emotions and Decisions: A Comparison of The Responses and Expectations of Forest Managers, An Environmental Group, And the Public. Environ. Behav. 1992, 24, 3-34. [CrossRef]

52. Torgler, B.; Garcia-Valiñas, M.A. The Determinants of Individuals' Attitudes Towards Preventing Environmental Damage. Ecol. Econ. 2007, 63, 536-552. [CrossRef]

53. Li, Q.; Chen, X.; Huang, Y. The Stability and Complexity Analysis of a Low-Carbon Supply Chain Considering Fairness Concern Behavior and Sales Service. Int. J. Environ. Res. Public Health 2019, 16, 2711. [CrossRef]

54. Karp, D.G. Values and Their Effect on Pro-Environmental Behavior. Environ. Behav. 1996, 28, 111-133. [CrossRef]

55. Post, J.E.; Altma, B.W. Managing the Environmental Change Process: Barriers and Opportunities. J. Organ. Chang. Manag. 1994, 7, 64-81. [CrossRef]

56. Goh, S.C. Managing Effective Knowledge Transfer: An Integrative Framework and Some Practice Implications. J. Knowl. Manag. 2002, 6, 23-30. [CrossRef]

57. Stapp, W.B.; Bennett, D.; Bryan, W.; Fulton, J.; MacGregor, J.; Nowak, P.; Wall, R. The Concept of Environmental Education. J. Environ. Educ. 1969, 1, 30-31. [CrossRef]

58. Wals, A.E.J. Learning Our Way to Sustainability. J. Educ. Sustain. Dev. 2011, 5, 177-186. [CrossRef]

59. Whetten, D.A. What Constitutes a Theoretical Contributions? Acad. Manag. Rev. 1989, 14, 490-495. [CrossRef]

60. Fitzgerald, Y.J. Cleaner Technologies for Sustainable Tourism: Caribbean Case Studies. J. Clean. Prod. 2005, 13, 117-134.

61. Fish, R.; Church, A.; Winter, M. Conceptualising Cultural Ecosystem Services: A Novel Framework for Research and Critical Engagement. Ecosyst. Serv. 2016, 21, 208-217. [CrossRef]

62. Du, S.; Bhattacharya, C.B.; Sen, S. Maximizing Business Returns to Corporate Social Responsibility (CSR): The Role of CSR Communication. Int. J. Manag. Rev. 2010, 12, 8-19. [CrossRef] 
63. Zou, T.; Huang, S.; Ding, P. Toward a Community-Driven Development Model of Rural Tourism: The Chinese Experience. Int. J. Tourism Res. 2014, 16, 261-271. [CrossRef]

64. Lane, B. Sustainable Rural Tourism Strategy: A Tool for Development and Conservation. J. Sustain. Tour. 1994, 2, 102-111. [CrossRef]

65. Hwang, D.; Stewart, W.P.; Ko, D. Community Behavior and Sustainable Rural Tourism Development. J. Travel Res. 2012, 51, 328-341. [CrossRef]

66. Pujari, D. D. Eco-Innovation and New Product Development: Understanding the Influences on Market Performance. Technovation 2006, 26, 76-85. [CrossRef]

67. Kim, M.; Chai, S. Implementing Environmental Practices for Accomplishing Sustainable Green Supply Chain Management. Sustainability 2017, 9, 1192. [CrossRef]

68. Miralles-Quiros, M.M.; Miralles-Quiros, J.L.; Arraiano, I.G. Are Firms That Contribute to Sustainable Development Valued by Investors? Corp. Soc. Responsib. Environ. Manag. 2017, 24, 71-84. [CrossRef]

69. Von Krogh, G.; Geilinger, N. Knowledge Creation in The Eco-System: Research Imperatives. Eur. Manag. J. 2014, 32, 155-163. [CrossRef]

70. Cloutier, S.; Pfeiffer, D. Sustainability Through Happiness: A Framework for Sustainable Development. Sustain. Dev. 2015, 23, 317-327. [CrossRef]

71. Rashid, Y.; Rashid, A.; Warraich, M.A.; Sabir, S.S.; Waseem, A. Case Study Method: A Step-By-Step Guide for Business Researchers. Int. J. Qual. Methods 2019, 18, 1609406919862424. [CrossRef] 